\title{
乳汁 の複合脂質に関する研究
}

4. 牛乳および人乳の各りえ脂質の脂肪酸組成

森

\author{
茂・土肥 達・三野 和雄 \\ （筜印乳業研究所） \\ (1966. 12.18 受付)
}

牛乳および人乳の中性脂肪の脂肪酸組成については多 数の報告があるが，それらのりえ脂質の脂肪酸組成につ いての報告は少ない。

乳汁以外のりえ脂質の脂肪酸の研究では, GETZ ら ら) $^{(4)}$

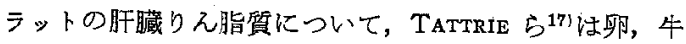
肺，醉母，人プラズマ, 牛プラス゚マなどのレシチンとリ ゾレシチンについて，KERR ら ${ }^{8)}$ は子牛脳のイノシトー ルりえ脂質について，SWEELEY15) は人プラズマのスフィ ンゴミェリンについて，O'BRIEN ら ${ }^{12)}$ は人脳のスフィン ゴミェリン，セラミド，セレブロシド，七レブロシド硫 酸について, STENAAGEN ら ${ }^{141}$ 恃人脳のスフィンゴミェリ ンについて報告している.

牛乳のりえ脂筫の脂肪酸組成については, BADINGS がケフォリン,レシチン，スフィンゴミェリンについて，

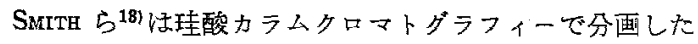
セレブロシド，ホスフォチジル・エタノール・アミン， ホスフォチジルセリン，レシチン，スフィンゴミエリン

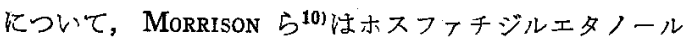
アミン，ホスフォチジルセリン，レシチンなどの位お よび $\beta$ 位の脂肪酸組成について, HAwKE ${ }^{6)}$ はバターミル クのケファリンとレシチンの $\alpha$ 位怙よび $\beta$ 位の脂肪酸 組成について報告している.

しかし人乳のりえ脂質の脂肪酸組成については, 古市 $ら^{3)}$ と工藤ら”の報告以外にはない。

著者らは牛乳持よび人乳のりえ脂質を珪酸カラムクロ マトグラフィーでケフォリン，レシチン，スフィンゴミ エリンに分画，精製し，各々のりん脂暨の脂肪酸組成を 測定してたので報告する.

$$
\text { 実験 }
$$

1. 試 料

牛乳試料は 10 月に札愰工場で集荷した 1 日分の混合

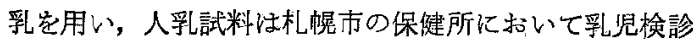
のため来所した健康な婦人から採取した 10 試料の混合 乳安用いた。

\section{2. りえ脂質の調製}

牛乳および人乳を蒸留水で 3 倍に稀䣋し，牛乳は $10^{\circ} \mathrm{C}$, 人乳は $40^{\circ} \mathrm{C}$ 亿保温し, $0.1 \mathrm{~N}$ 酶酸で $\mathrm{pH} 4.6$ K し，カゼインとともに全脂質を沈澱させ，一夜放置後汇 過，沈澱を蒸留水で充分洗湺し，エチルフルコール：エ チルエーテル：クロロホルム $=3: 1: 1$ の溶媒で全脂質

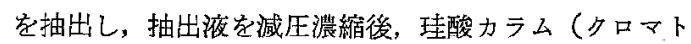
用珪酸マーリンクロット社製 $60 \mathrm{~g}$ ，セシイト $-545 ， 30 \mathrm{~g}$ $40 \times 2.8 \phi \mathrm{cm})$ 亿吸着させ, 第 1 表の溶媒で順次溶出し, (4)(5)のフラクションを集め溶媒を減圧留去し, 全りえ脂 質の試料とした。

3. りん脂質の分画および精製

第 1 表 溶 出 溶 媒

\begin{tabular}{|c|c|c|c|c|}
\hline No. & 溶 & |混合比| & 量 & 溶 出 物 \\
\hline 1 & $\begin{array}{l}\text { サロホルム: } \\
\text { チルフルコール }\end{array}$ & $98: 2 \mid$ & 300 & $\begin{array}{l}\text { 中性脂 肪 } \\
\text { コレステール }\end{array}$ \\
\hline 2 & ア 七 & - & 400 & 糖 脂 \\
\hline 3 & $\begin{array}{l}\text { ロロホルム: } \\
\text { チルオルコール }\end{array}$ & $98: 2$ & 300 & \\
\hline 4 & " & $4: 1$ & 100 & り え 脂 質 \\
\hline 5 & "l & $1: 4$ & 400 & "l \\
\hline
\end{tabular}

第2 表 溶出溶 媒

\begin{tabular}{l|cr|c|l}
\hline \hline No. & 溶 & 媒 & 混合比 & \multicolumn{2}{c}{ 量 } \\
\hline ml
\end{tabular}

(珪酸 $30 \mathrm{~g}$ セライト $-54515 \mathrm{~g}$ カ5ム $35 \times 2 \phi \mathrm{cm}$ ) 
りえ脂質の分画，精製にも珪酸カラムクロマトグラフ イーを用い，第 2 表の溶媒で順次溶出し，クロロホル ム : メチルアルコール $=4: 1$ の溶媒以下を $50 \mathrm{~m} l$ ずつ 分取した. 各フラクションのりえ定量し，そのクロマ トグラムを第1図に示した。

第 I四における溶出番号(4)(5)(6)它ケフリン区分，(16)

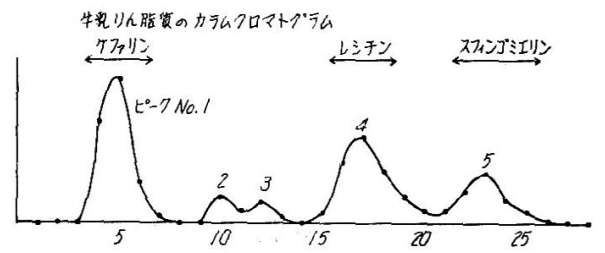

人的りん脂筫のカラムクロマなブラム

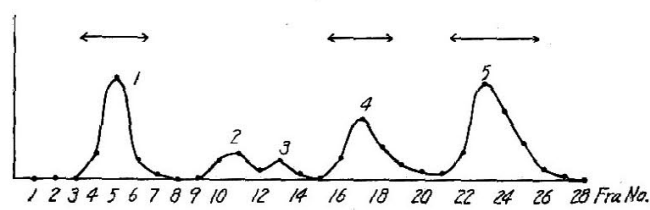

第 1 这 りえ脂筫のカラムクロマトグラム 上: 牛乳

Fra No. 1 と No. 3 クロロホルム:

Fra No. 2

メチルフルコール $=98: 2(\mathrm{C}: \mathrm{M})$

Fra No. $4 \sim$ No. 9 フセトン

Fra $10 \sim N=3: 2$

Fra No. $16 \sim$ No. $21 \quad C: M=1: 1$

Fra No. $22 \sim$ No. $28 \quad$ C : $M=1: 4$
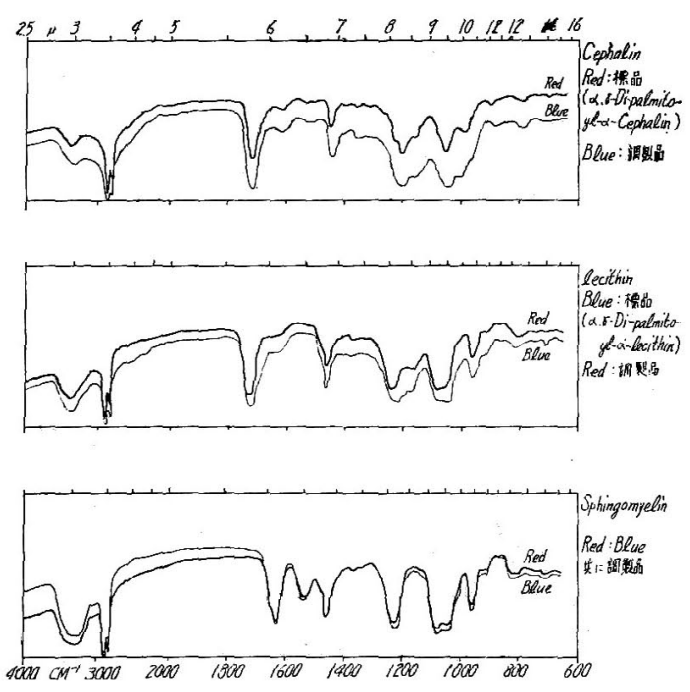

第 2 図りえ脂質の赤外線吸収スペクトル

$$
\begin{aligned}
& \text { 上: ケファリン } \\
& \text { 中: レシ*ン } \\
& \text { 下: スフィンゴェリン }
\end{aligned}
$$

スフィンゴミエリンは特乳から珪酸カラムクロマトグラフ

イーで分画精製し，澌尿クロマトグラフィーで単一スボット

として得られたもの。

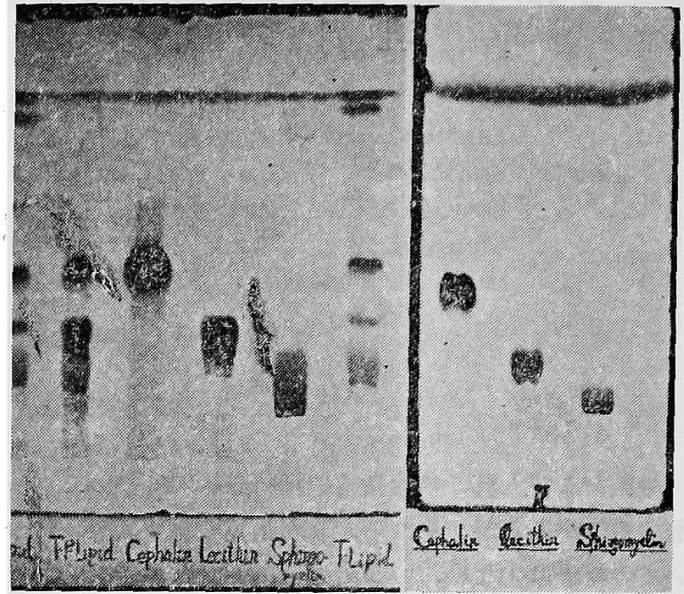

左：1 回目のクロマト分画物 右：精製試料

第 3 図牛乳りえ脂質の薄層クロマトグラム

(17)(18)をレシチン区分，(22)(2020126)をスフィンゴミエリン区 分として集め，溶媒を減圧留去し，各フラクションにつ いて，ふたたび珪酸カラムタロマトダラフィーで精製し た. 分画したりえ脂質については赤外線吸収スペクトル により同定し，薄層クロマトグラフィーにより純度它検 定した。その赤外線吸収スペクトルと薄層りロマトグラ 厶它第 2 図，第3 図，第4図に示した。な欂層クロマ トグラフィーは前報2に示した方法による。

\section{4. りん脂質の脂肪酸メチルエステルの調製}

分画したりえ脂質を $\mathrm{MeOH}-\mathrm{H}_{2} \mathrm{SO}_{4}$ エステル交換法で 脂肪酸メチルエステルを調製した。すなわち，りん脂質 約 $50 \mathrm{mg}$ に無水メチルアルコール $20 \mathrm{~m} l$ と濃硫酸 $1 \mathrm{~m} l$ を混合乙，8時間加熱還流後，反応液に水 $20 \mathrm{ml}$ を加え， エチルェーテルで生成した脂肪酸メチルエステルを抽出 した. 3 回抽出したエーテルを合せて, 水 $10 \mathrm{ml}$ で 2 回 洗桬し, 芒硝で脱水乾燥, 汇過し溶媒を減生留去し脂肪 酸メチルエステルを得た。

\section{5. 標準脂肪酸メチルエステルの調製}

脂肪酸メチルエステルの標品は市販品を用いた。 エス

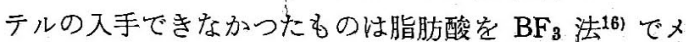
チルエステルを調製した。すなわち, 試料安メチルアル コールに溶解し， $\mathrm{BF}_{3}$ のエチルエーテル溶液を滴下し約 30 分加熱還流した後，水を加えてエチルエーテルで抽 出し, エーテル層を弪硝で脱水乾燥後, エチルエーテル 芝減压留去しエステルを它得た。使用した各標準脂肪酸丈 チルエステルの純度它第3表に示した。

6. ガスクロマトグラフィーの運転条件

充㙏剂 固定相にセライト 545

液相にポリエチレングライコールサクシネ $-卜$ 
“牛乳, 人乳各りえ脂質の脂肪酸組成

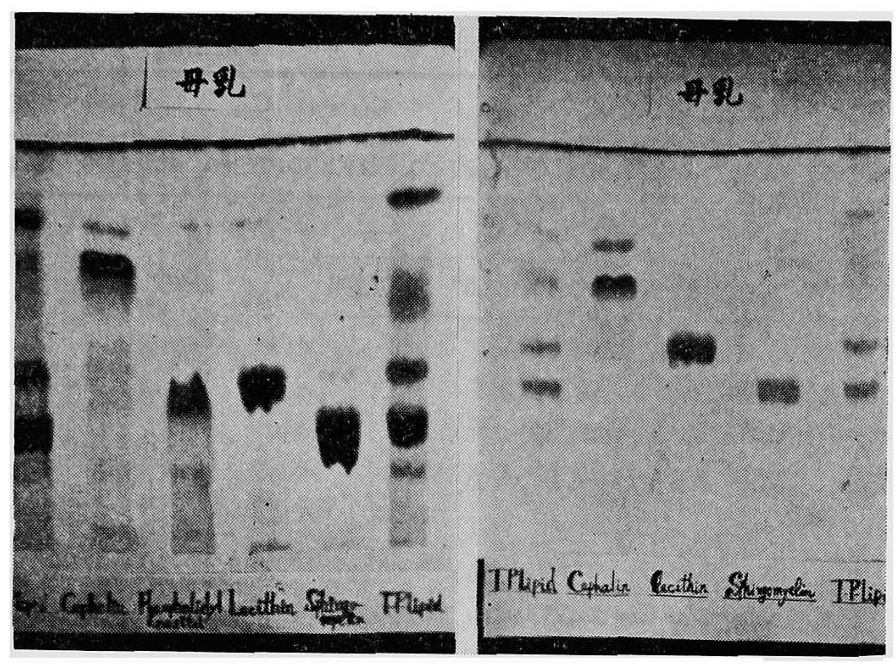

左: 1 回目のクロマト分画物

右: 䊑製試料

第4 図人乳りて脂質の薄層クロマトグラム

第3 表 標準脂肪酸メチルエステルの純度

\begin{tabular}{|c|c|c|c|c|c|}
\hline 脂肪酸 & 純 度 & 脂肪酸 & 度 & 脂肪酸 & 純 \\
\hline $\mathrm{C}_{6}$ & $100.0 \%$ & $\mathrm{C}_{14}$ & $97.01 \%$ & $\mathrm{C}_{18}^{\Delta 1}$ & $100.0 \%$ \\
\hline$C_{8}$ & 97.79 & $\mathrm{C}_{16}$ & 94.45 & $\mathrm{C}_{18}^{\Delta 2}$ & 100.0 \\
\hline $\mathrm{C}_{10}$ & 92.07 & $C_{18}$ & 89.54 & $\mathrm{C}_{18}^{\Delta 3}$ & 100.0 \\
\hline$C_{12}$ & 100.0 & $\mathrm{C}_{20}$ & 100.0 & & \\
\hline
\end{tabular}

固定相に対し液相を $30 \%(W / W)$ 担持させた。 カラムの長さ $3 \mathrm{~m}$
恒温槽温度 $220^{\circ} \mathrm{C}$, 試料室温度 $320^{\circ} \mathrm{C}$ キャリヤーガス $\mathrm{He}$ 流量 $30 \mathrm{ml} / \mathrm{min}$

隇哀器感度 $4,8 \mathrm{mV}$, ブリッヂ電流 $150 \mathrm{~mA}$ 試料注入量 $2 \sim 5 \mu l$

装置 島津製 GC-2A 型 実 験 結 果

1.フィルムトレッサーの均一性の検討

クロマトグラムを重量換算する用紙に航空写真描写用 に使用されているフィルムトレッサーを使用した.トレ ッサーの均一性を検討するため, 任意に 3 枚とりだし，
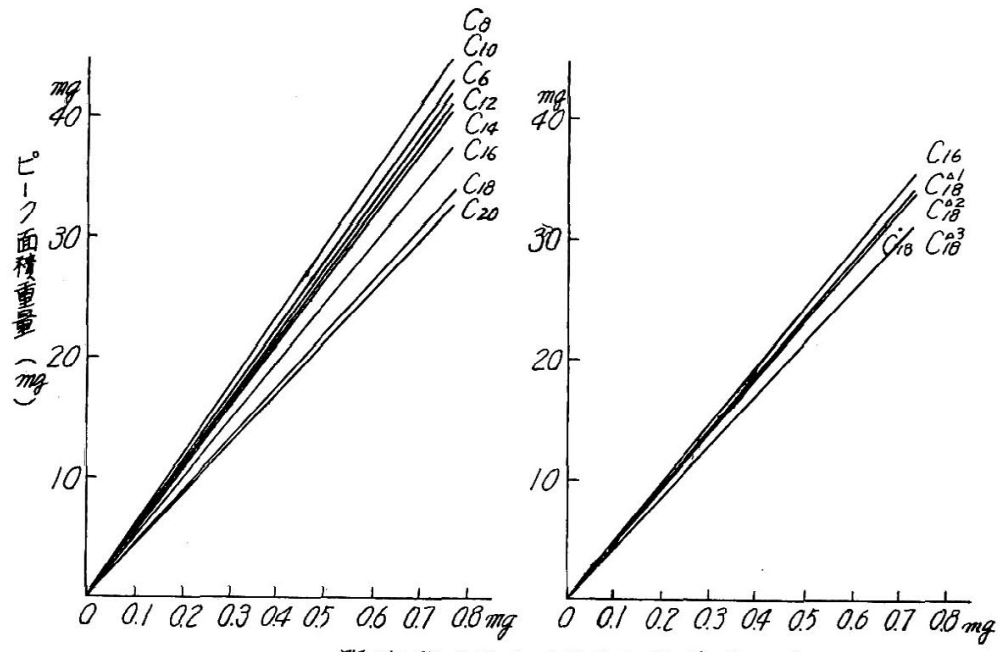

脂肪酸人干儿エステル重量（mg）

左: $\mathrm{C}_{6} \sim \mathrm{C}_{2}$ 跑和脂眆酸

右: $\mathrm{C}_{18}$ 不䣄和脂䄱酸

第 5 図 脂肪酸メチルエステル重量とピーク面䅡重量との関係 
森・土肥・三野

第 4 表 換 算 保 数

\begin{tabular}{|c|c|c|c|c|c|c|c|c|c|c|c|}
\hline 脂肪酸 & $\mathrm{C}_{8}$ & $\mathrm{C}_{10}$ & $\mathrm{C}_{12}$ & $\mathrm{C}_{14}$ & $C_{16}$ & $\mathrm{C}_{18}$ & $\mathrm{C}_{20}$ & $\mathrm{C}_{22}$ & $\mathrm{C}_{28}$ & $\mathrm{C}_{24}$ & $\mathrm{C}_{12}^{\Delta 1}$ \\
\hline 係 数 & 0.01579 & 0.01664 & 0.01760 & 0.01806 & 0.01960 & 0.02192 & 0.02280 & 0.02288 & 0.2292 & 0.02296 & 0.01759 \\
\hline 脂肪酸 & $\mathrm{C}_{11}^{\Delta 1}$ & $\mathrm{C}_{18}^{\Delta 1}$ & $\mathrm{C}_{18}^{\Delta 1}$ & $\mathrm{C}_{18}^{\Delta 2}$ & $\mathrm{C}_{1 B}^{\Delta s}$ & $\mathrm{C}_{84}^{\Delta 1}$ & & & & & \\
\hline 係 数 & 0.01805 & 0.01959 & 0.02048 & 0.02079 & 0.02237 & 0.02295 & & & & & \\
\hline
\end{tabular}

1 枚から $9 \mathrm{~cm}^{2}$ の大きさに 10 枚切りとり，炎の重量を 坪量し1枚のトレッサーの部位による差, 就よび異つた トレッサー間の差夌検定した結果，5\%の危険率で有意 差はなかつた。

2. 梌量線の作成

$\mathrm{C}_{6}, \mathrm{C}_{10}, \mathrm{C}_{14}, \mathrm{C}_{1 \mathrm{~B}}$, と $\mathrm{C}_{8}, \mathrm{C}_{12}, \mathrm{C}_{16}, \mathrm{C}_{20}$ および $\mathrm{C}_{16}$, $\mathrm{C}_{18}^{\Delta 1}, \mathrm{C}_{18}^{\Delta 2}, \mathrm{C}_{18}^{\Delta 3}$ の3 ダルーブにわけ, 各タ 400〜600 $\mathrm{mg}$ を正確化 $10 \mathrm{~m} l$ のメスフラスコに科量し, ニチルエ 一テルでメスフップし，その $2,3,4,5,6,7,8,9 \mu l$ 家注入し，各ふのガスクロマトグラムをフィルムトレッ サーに军し，その面積重量を科量し，脂肪酸メチルエス テル重量とピーク面積重量との関係を求めた。よこ軸 (X) に脂肪酸メチルエステルの注入絶対重量 $(\mathrm{mg})$ 家と りこてれ対忘するピーク面積重量 (mg) をたて軸 ( $\mathrm{Y}$ ) に求め， $\mathrm{Y}=\alpha \mathrm{X}$ の直線関係が成立寸ると仮定し，之の 回帰係数 $\alpha=\Sigma X Y / \Sigma Y^{2}$ を求めた. 各脂肪酸メチルエ ステルの回帰係数から得た検量線它第 5 图见示した。

各脂肪酸メチルエステルのピーク面糟重量からェステ 几の絶対重量を求的る補正係数 a 求め, ピーク面積重 量から直接むとの脂肪酸重量を求める換算係数它求好 た.

（a〕との脂肪酸分子量/脂肪酸メテルエステル分子量） その換算係数を第 4 表に示した.

3. 㟶素数と保持時間の関係

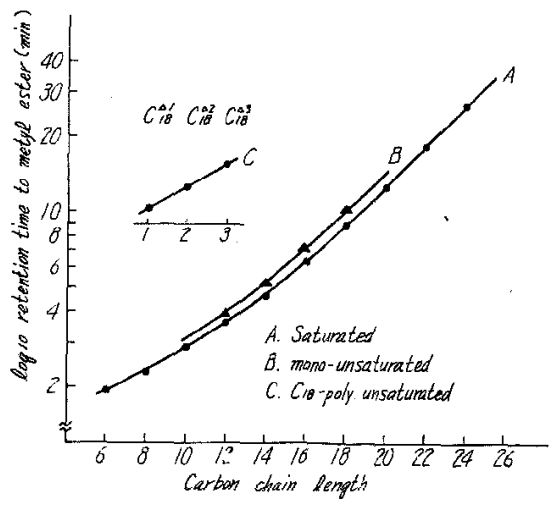

第 6 図 脂肪酸の炭紊数と保持時間の関係

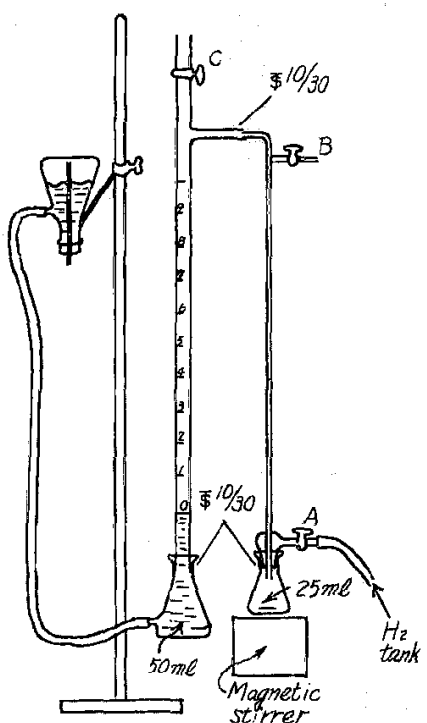

第7図 微量水素添加装箈（JoHN ら

ガスクロマトグラムの各脂肪酸メチルエステルの保持 時間を測定し，虫の関係を第 6 図に示した。主なピータ 冲第 6 図に基づいて同定したが $\mathrm{C}_{18}^{\Delta 2}$ 乙 $\mathrm{C}_{20}$ が全く重な り，そのままでは定量できないため，試料を水素添加し $\mathrm{C}_{18}^{\Delta 2}$ 它 $\mathrm{C}_{18}$ に变えた後， $\mathrm{C}_{20}$ の定量を行なつた。

4. 水素添加法

試料の水素添加には第 7 図 $^{7)}$ に示す装置を用い，塩化 パラジウムを触媒として行なつた，試料の脂肪酸メチル エステルを無水メチルフルコールに溶解し，触媒を添加 後水素ガスを充渾, 液面之接触させ, 䄪 15 分攪汼する ことにより反応㤏了した。

5. 測定結果

同定したクロマトグラムをトレッサーに写し，そのピ 一ク面積の重量它科量し，換算係数を乗して脂肪酸の重 量 \%としたもの第5 衰に示した。

考察

りえ脂望の分画には，珪酸カラムクロマトグラフィー を用い5成分に分画したが，その主成分であるケフォリ 
牛乳，人乳各り九脂質の脂肪酸組成

第 5 表 牛乳斿よび人乳りえ脂質の脂肪酸組成

\begin{tabular}{|c|c|c|c|c|c|c|c|c|}
\hline \multirow{2}{*}{ 脂肪酸 } & \multicolumn{2}{|c|}{ 全りえ脂質 } & \multicolumn{2}{|c|}{ ケフォリン } & \multicolumn{2}{|c|}{ 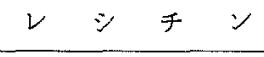 } & \multicolumn{2}{|c|}{ スフィンゴミエリン } \\
\hline & 牛 乳 & 人 乳 & 4 乳 & 人乳 & 牛 乳 & 人 乳 & 乳 & 人 乳 \\
\hline $\mathrm{C}_{8}$ & 0.29 & - & 0.82 & - & - & - & - & - \\
\hline$C_{10}$ & 0.50 & 0.71 & 0.24 & 0.49 & 0.53 & 0.54 & - & - \\
\hline $\mathrm{C}_{12}$ & 1.22 & 0.82 & 0.45 & 0.91 & 0.68 & 0.79 & 0.47 & 0.95 \\
\hline$C_{14}$ & 2.98 & 2.58 & 1.02 & 1.15 & 3.68 & 1.65 & 1.36 & 2.72 \\
\hline$C_{14}^{\Delta 1}$ & 0.76 & 0.55 & 0.44 & - & 0.96 & 0.28 & 0.31 & - \\
\hline$C_{16}$ & 15.74 & 14.12 & 12.29 & 8.47 & 30.08 & 13.67 & 20.66 & 7.78 \\
\hline $\mathrm{C}_{16}^{\Delta 1}$ & 1.07 & 1.93 & 4.04 & 0.88 & 2.60 & 0.94 & 1.11 & - \\
\hline $\mathrm{C}_{18}$ & 14.68 & 21.79 & 13.37 & 30.90 & 8.55 & 25.38 & 2.31 & 9.29 \\
\hline$C_{18}^{\Delta 1}$ & 35.67 & 11.23 & 53.45 & 17.49 & 40.53 & 13.03 & 0.81 & 1.62 \\
\hline $\mathrm{C}_{18}^{\Delta 3}$ & 2.81 & 9.46 & 5.03 & 14.26 & 8.95 & 20.79 & 0.52 & - \\
\hline $\mathrm{C}_{18}^{\Delta 8}$ & 2.83 & 2.80 & 2.63 & 4.84 & 0.93 & 3.63 & - & - \\
\hline $\mathrm{C}_{20}$ & 3.82 & 8.70 & 4.01 & 6.31 & 1.02 & 5.26 & 2.38 & 12.93 \\
\hline $\mathrm{C}_{22}$ & 5.98 & 5.69 & 2.22 & 4.44 & 1.51 & 3.70 & 13.08 & 21.75 \\
\hline $\mathrm{C}_{23}$ & 7.04 & 4.35 & - & 2.39 & - & 3.75 & 25.20 & 5.50 \\
\hline $\mathrm{C}_{24}$ & 4.63 & 7.71 & - & 4.58 & - & 6.61 & 19.79 & 14.70 \\
\hline$C_{24}^{\Delta 1}$ & - & 7.57 & - & 2.89 & - & - & 12.00 & 22.77 \\
\hline
\end{tabular}

ン、レシチン，スフィンゴミエリンについてとの脂肪酸 組成を測定した，第 1 図のピーク No. 2 呫よび No. 3 法郝線吸収スペクトルからを机でれホスフチジルイ ノシトールおよびレシチンと推定されるが量が少ないた め脂肪酸の定量注行なかなかつた。

第3 図性牛乳りえ脂質について 1 回目のクロマト分画 物と再精製したものの薄層クロマトグラムで，牛乳りえ 脂質はほぼ完全に近く分画, 精製できたと考光られる。

第 4 図は人乳りえ脂質について1回目のクロマト分画 物と再精製したものの薄層クロマトグラムである.ケフ フリンは 2 度精製したが単一物質とならなかつた・レシ チンとスフィンゴミエリンについては注とえど純䊉に分 画できたと考元られる。

各脂肪酸メチルエステルの回帰係数から得た検量線法 第 5 図に示す通りであるが， $\mathrm{C}_{8} \sim \mathrm{C}_{20}$ までの飽和脂肪酸 について流肪酸の炭素数が多くなるにつれて脂肪酸从 チルェステル単位重量当りのピー多面積重量は順次小さ くなつた。 $C_{18}$ の不飽和脂肪酸については不飽和度が大 きくなるにつれて，脂肪酸メチルエステル単位重量当り のピーク面積重量は順次小さくなつた.

ピークの同定には脂肪酸の炭素数と保持時間の関俰, 第6図に基づいて行なつたが， $\mathrm{C}_{18}^{\Delta 2}$ と $\mathrm{C}_{20}$ とが重なり， そのまをでは定量不可能であったので, 試料を水素添加 し $\mathrm{C}_{18}^{\Delta \mathrm{a}}$ を $\mathrm{C}_{18}$ に变えた後, $\mathrm{C}_{20}$ のピークを定量した。し
たがって， $\mathrm{C}_{20}$ の中には $\mathrm{C}_{20}^{\Delta 1}, \mathrm{C}_{20}^{\Delta 2}, \mathrm{C}_{20}^{\Delta 3} . \mathrm{C}_{20}^{\Delta 4}$ など も含まれるが，量的に少なく一括して $\mathrm{C}_{20}$ として表わし た.

$\mathrm{C}_{34}$ は第 6 図に基づいて同定したが， $\mathrm{C}_{23}$ については $\mathrm{C}_{22}$ ¿ $\mathrm{C}_{24}$ の間にあつて，水菜添加後るなくならないと゚ ークを $\mathrm{C}_{28}$ とし， $\mathrm{C}_{24}^{\Delta 1}$ は $\mathrm{C}_{24}$ のすぐつぎのピークで, 水素添加後 $\mathrm{C}_{24}$ のピークに重なったものとした． $\mathrm{C}_{25}$ 以 上の脂肪酸む微量認められたが（特にスフィンゴミエリ ン)，一応 $\mathrm{C}_{24}^{\Delta 1}$ までを目標に定量した。これらについて は今後検討定重衫たい。

著者らの測定した脂肪酸組成を他の文献值と比較する と，ケファリンについては第6表に示す通りで，牛乳々 フォリンは BADINGS, HAWKE らの值と大体一致するが,

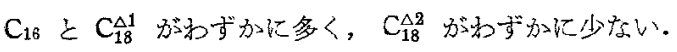

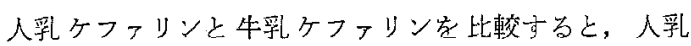
は $\mathrm{C}_{18}$ 之 $\mathrm{C}_{18}^{\Delta 8}$ が多く, $\mathrm{C}_{18}^{\Delta 1}$ が少ない. $\mathrm{C}_{18}^{\Delta 1}$ は牛乳の $1 / 3$ である。しかし人乳は $\mathrm{C}_{22}, \mathrm{C}_{23}, \mathrm{C}_{24}, \mathrm{C}_{24}^{\Delta 1}$ の合計が $10 \%$ 以上西り，牛乳との大きな違いである。

次にレシチンについての比較を第 7 表に示した. 牛乳 レシチンは交献值と大きな差はなく、わずが $\mathrm{C}_{18}^{\Delta 1}$ が多

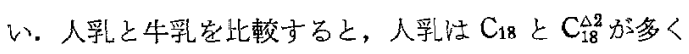
$\mathrm{C}_{16}$ 乙 $\mathrm{C}_{18}^{\Delta 1}$ が少ない。 またケフフリンと同様に $\mathrm{C}_{30}$ $C_{24}$ が約 $20 \%$ あり，との点牛乳との差が大きい。 
森・土肥・罪野

第6 表 牛乳敊よび人乳ケファリンの脂肪酸組成

\begin{tabular}{|c|c|c|c|c|c|c|c|}
\hline \multirow{2}{*}{ 脂 } & \multirow{2}{*}{ 肪 酸 } & 分 & 析 & BADINGS $^{1)}$ & \multirow{2}{*}{$\begin{array}{c}\mathrm{HAWKE}^{8\}} \\
\text { バターミルタ }\end{array}$} & \multirow{2}{*}{$\left|\begin{array}{l}\text { SMITH \& LoWRY } \\
\text { ヘタターミルク, PE }\end{array}\right|$} & \multirow{2}{*}{$\begin{array}{c}\text { MORRISON \& } \\
\text { JACK \& SMITH }{ }^{101} \\
\text { 牛乳 } \mathrm{PE}\end{array}$} \\
\hline & & 乳 & 乳 & 乳 & & & \\
\hline & $C_{10}$ & 0.49 & 0.24 & - & - & - & - \\
\hline & $\mathrm{C}_{12}$ & 0.91 & 0.45 & 0.4 & 0.4 & 0.3 & 0.3 \\
\hline & $C_{14}$ & 1.15 & 1.02 & 1.5 & 1.35 & 0.7 & 1.5 \\
\hline & $C_{14}^{\Delta 1}$ & - & 0.44 & 0.1 & - & 0.1 & 0.1 \\
\hline & $\mathrm{C}_{16}$ & 8.47 & 12.29 & 9.2 & 9.85 & 8.3 & 11.7 \\
\hline & $C_{16}^{\Delta 1}$ & 0.88 & 4.04 & 1.2 & 1.4 & 1.9 & 2.1 \\
\hline & $C_{18}$ & 30.90 & 13.37 & 19.1 & 12.8 & 8.5 & 10.5 \\
\hline & $C_{18}^{\Delta 1}$ & 17.49 & 53.45 & 48.0 & 50.95 & 53.6 & 46.7 \\
\hline & $C_{18}^{\Delta 2}$ & 14.26 & 5.03 & 8.9 & 9.0 & 13.4 & 12.4 \\
\hline & $\mathrm{C}_{18}^{\Delta 8}$ & 4.84 & 2.63 & 1.8 & 2.2 & 4.3 & 3.4 \\
\hline & $\mathrm{C}_{20}$ & 6.31 & 4.01 & 0.7 & 0.25 & - & 0.3 \\
\hline & $\mathrm{C}_{22}$ & 4.44 & 2.22 & 0.9 & - & 1.9 & 0.2 \\
\hline & $\mathrm{C}_{2 \mathrm{a}}$ & 2.39 & - & 0.5 & - & - & - \\
\hline & $\mathrm{C}_{24}$ & 4.58 & - & 0.4 & - & - & - \\
\hline & $C_{24}^{\Delta 1}$ & 2.89 & - & 0.6 & - & - & - \\
\hline
\end{tabular}

$\mathrm{PE}:$ ホスファチジル・ニタノールフミン

第7表 牛乳および人乳レシチンの脂肪酸組成

\begin{tabular}{|c|c|c|c|c|c|c|c|c|}
\hline \multirow{2}{*}{ 脂 } & \multirow{2}{*}{ 肪 酸 } & 分 & 值 & BADINGS $^{11}$ & \multirow{2}{*}{$\frac{\mathrm{HAWKE}^{6)}}{\text { ヘターミルタ }}$} & \multirow{2}{*}{$\mid \begin{array}{l}\text { Smith \& LOWRY } \\
\text { バターミルク }\end{array}$} & \multicolumn{2}{|c|}{$\begin{array}{l}\text { MORRISON \& } \\
\text { JACK \& SMI TH } \\
\end{array}$} \\
\hline & & 人乳 & 乳 & 牛 乳 & & & 牛 & 乳 \\
\hline & $\mathrm{C}_{10}$ & 0.54 & 0.53 & - & - & - & & - \\
\hline & $C_{12}$ & 0.79 & 0.68 & 0.5 & 0.25 & 0.3 & & 0.7 \\
\hline & $\mathrm{C}_{14}$ & 1.65 & 3.68 & 6.0 & 5.6 & 1.0 & & 8.4 \\
\hline & $\mathrm{C}_{14}^{\Delta 1}$ & 0.28 & 0.96 & 0.4 & - & 0.4 & & 0.1 \\
\hline & $\mathrm{C}_{16}$ & 13.67 & 30.08 & 30.7 & 35.4 & 26.1 & & 36.4 \\
\hline & $C_{16}^{\Delta 1}$ & 0.94 & 2.60 & 2.1 & 2.3 & 3.0 & & 0.6 \\
\hline & $\mathrm{C}_{18}$ & 25.38 & 8.55 & 11.7 & 10.0 & 8.2 & & 11.1 \\
\hline & $\mathrm{C}_{18}^{\Delta 1}$ & 13.03 & 40.53 & 35.9 & 31.15 & 34.3 & & 25.7 \\
\hline & $\mathrm{C}_{18}^{\Delta 2}$ & 20.79 & 8.95 & 4.7 & 5.0 & 11.9 & & 5.3 \\
\hline & $\mathrm{C}_{18}^{\Delta 8}$ & 3.63 & 0.93 & 1.1 & 2.7 & 3.5 & & 1.1 \\
\hline & $\mathrm{C}_{20}$ & 5.26 & 1.02 & 0.6 & 0.1 & - & & 0.3 \\
\hline & $\mathrm{C}_{22}$ & 3.70 & 1.51 & 0.2 & - & 1.1 & & 0.1 \\
\hline & $\mathrm{C}_{23}$ & 3.75 & - & - & - & - & & - \\
\hline & $\mathrm{C}_{34}$ & 6.61 & - & - & - & - & & - \\
\hline
\end{tabular}

スフィンゴミエリンについては第8表に示す通りで， 研究者によつてま它占である. 著者らの牛乳スフィン ゴミ土片值は $\mathrm{C}_{18}, \mathrm{C}_{18}^{\Delta 1}, \mathrm{C}_{18}^{\Delta 2}, \mathrm{C}_{18}^{\Delta 3}$, 肪きわめて少 なく， $\mathrm{C}_{22}, \mathrm{C}_{28}, \mathrm{C}_{24}$ が多く合計で $70 \%$ 以上であった。 著者らの值と比較して，BADINGS の值注 $\mathrm{C}_{14}, \mathrm{C}_{16}, \mathrm{C}_{18}$,

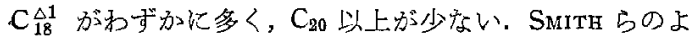

うに同じスフィンゴミエリンでを珪酸カラムクロマトグ ラフィーでの溶出の早いむの ( Sph 1) と投そいるの (Sph 2) とでは，その脂肪酸組成に大きな差がある. Sph 1 注著者らの值上よく似ているが, Sph 2 は C 1 が $58 \%$ もあり全く異なつている，MORRISON らの值江漖者 らの值と良く一致している。人乳と牛乳比較すると， 
牛乳，人乳各りえ脂質の脂肪酸組成

第8 表，牛乳および人乳スフィンゴミェリンの脂肪酸組成

\begin{tabular}{|c|c|c|c|c|c|c|c|}
\hline \multirow{2}{*}{ 脂 } & \multirow{2}{*}{ 肪 酸 } & & 析 值 & BADINGS ${ }^{17}$ & \multicolumn{2}{|c|}{ SMITH \& LoWRY ${ }^{18)}$} & $\begin{array}{c}\text { MoRRISON \& } \\
J_{A C K} \& \text { SMITH }\end{array}$ \\
\hline & & 人 乳 & 牛 乳 & 牛 乳 & $\begin{array}{c}\text { バターミルク } \\
(\mathrm{Sph} 1)\end{array}$ & $\begin{array}{c}\text { バターミルク } \\
(\operatorname{Sph} 2)\end{array}$ & 牛 乳 \\
\hline & $\mathrm{C}_{10}$ & - & - & - & 0.7 & 0.3 & - \\
\hline & $\mathrm{C}_{13}$ & 0.95 & 0.47 & 0.9 & 1.1 & 0.5 & 0.3 \\
\hline & $\mathrm{C}_{11}$ & 2.72 & 1.36 & 9.5 & 4.8 & 6.5 & 2.5 \\
\hline & $C_{14}^{\Delta 1}$ & - & 0.31 & 0.5 & 0.4 & $\operatorname{tr}$ & - \\
\hline & $\mathrm{C}_{16}$ & 7.78 & 20.66 & 30.5 & 24.5 & 58.0 & 22.1 \\
\hline & $\mathrm{C}_{16}^{\Delta 1}$ & - & 1.11 & 0.7 & 1.7 & 1.2 & 0.8 \\
\hline & $\mathrm{C}_{18}$ & 9.29 & 2.31 & 6.3 & 3.3 & 3.5 & 4.5 \\
\hline & $\mathrm{C}_{18}^{\Delta 1}$ & 1.62 & 0.81 & 9.6 & 6.4 & 7.1 & 5.0 \\
\hline & $\mathrm{C}_{18}^{\Delta 8}$ & - & 0.52 & 1.2 & 2.2 & 2.6 & 0.9 \\
\hline & $\mathrm{C}_{18}^{\Delta 3}$ & - & - & 0.2 & 1.4 & 1.5 & - \\
\hline & $\mathrm{C}_{20}$ & 12.93 & 2.38 & 0.6 & - & - & 0.6 \\
\hline & $\mathrm{C}_{22}$ & 21.75 & 13.08 & 8.5 & 14.2 & 5.2 & 14.7 \\
\hline & $\mathrm{C}_{23}$ & 5.50 & 25.20 & 13.1 & 21.5 & 6.2 & 27.0 \\
\hline & $\mathrm{C}_{24}$ & 14.70 & 19.79 & 8.2 & 8.6 & 2.6 & 14.8 \\
\hline & $C_{24}^{\Delta 1}$ & 22.77 & 12.00 & 2.2 & - & - & 1.9 \\
\hline
\end{tabular}

第9 表 人乳および他の器官のスフィンジミェ リンの脂肪酸組成

\begin{tabular}{|c|c|c|c|c|c|}
\hline \multirow[b]{2}{*}{ 脂肪酸 } & \multirow{2}{*}{ 人乳 } & \multirow{2}{*}{$\frac{\text { SWEELEX }^{15)}}{\text { 人プラズマ }}$} & \multirow{2}{*}{ 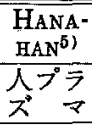 } & \multirow{2}{*}{$-\frac{\begin{array}{c}\text { NEL- } \\
\text { SON }\end{array}{ }^{11)}}{人 セ ゙ ラ ム}$} & O'BRIEN ${ }^{12)}$ \\
\hline & & & & & 牛 脳 \\
\hline $\mathrm{C}_{16}$ & 7.78 & 41.7 & 48 & 33.9 & 5.9 \\
\hline$C_{18}$ & 9.29 & 9.4 & 18 & 18.3 & 40.1 \\
\hline$C_{18}^{\Delta 1}$ & 1.62 & 0.7 & 2 & 13.8 & 0.7 \\
\hline$C_{18}^{\Delta 2}$ & - & - & 4 & 21.6 & - \\
\hline $\mathrm{C}_{20}$ & 12.93 & 3.9 & - & - & 0.4 \\
\hline$C_{30}^{\Delta 4}$ & 一 & - & 3 & 6.7 & - \\
\hline $\mathrm{C}_{22}$ & 21.75 & 12.1 & 18 & - & 3.5 \\
\hline $\mathrm{C}_{23}$ & 5.50 & 5.1 & - & 一 & 2.8 \\
\hline$C_{24}$ & 14.70 & 8.9 & - & - & 10.7 \\
\hline$C_{84}^{\Delta 1}$ & 22.77 & 14.1 & - & - & 24.6 \\
\hline
\end{tabular}

人乳は $\mathrm{C}_{18}, \mathrm{C}_{20}, \mathrm{C}_{22}, \mathrm{C}_{21}^{\Delta 1}$ が多人, $\mathrm{C}_{16}, \mathrm{C}_{23}$ が少ない。特 $飞 \mathrm{C}_{28}$ が人乳に少なく，牛乳に多く，人乳と牛乳の差が 著しい. 人乳，牛乳々もに $\mathrm{C}_{20} \sim \mathrm{C}_{20}$ の割合注 $70 \%$ 以上 であつた。

つぎに人乳と他の器官のスフィンゴミェリンの脂肪酸 組成の値を比皎すると第 9 表の通りで，人乳と人プラス゚ マ，人ゼラムとの間にもかなり差竐りり，人プラズマで は $\mathrm{C}_{16}$ が $40 \%$ むめり，研究者比よつても值は翼なる。牛 脳では $C_{18}$ が $40 \% ， C_{24}^{\Delta 1}$ が $25 \%$ るむる。

STENHAGEN ら ${ }^{14}$ は人脸スフィンゴミェリンの脂肪酸に
ついて年龄および脱随疾患者との比較をしている．その 一部岁第 10 表に示す.

これによると年齡が大きくなるにつれて $\mathrm{C}_{24}^{\Delta}$ が激增し $\mathrm{C}_{22} \sim \mathrm{C}_{26}$ 无堌加の傾向にある. これに反乙，脱㵦疾患者

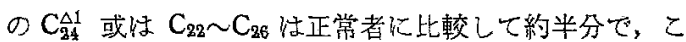
れらの脂肪酸の減少が著しい。このよ5に脳発育に重要 な意義を持つ $\mathrm{C}_{24}^{\Delta 1}$ 或は $\mathrm{C}_{22}$ 以上の高級脂肪酸が 人乳ス

第 10 表 人脳スフィンゴミエリンの脂肪酸組成 年齢および脱故疾患者との比較 (STENHAGEN ら ${ }^{14) に よ る) ~}$

\begin{tabular}{|c|c|c|c|c|c|c|}
\hline \multirow{2}{*}{ 脂肪酸 } & \multicolumn{2}{|l|}{ 正 } & \multicolumn{2}{|c|}{ 者 } & \multicolumn{2}{|c|}{ 脱喃疾患者 } \\
\hline & $\begin{array}{l}\text { 胎 児 } \\
33 \text { 週 } \\
\end{array}$ & $\begin{array}{l}\text { 生 後 } \\
\text { 14\%目 }\end{array}$ & 4 年 & 6 年 & $\begin{array}{l}4 \\
6 \text { ク月 } \\
\end{array}$ & 29 年 \\
\hline $\mathrm{C}_{16}$ & $8.3^{\%}$ & $\begin{array}{c}\% \\
3.0\end{array}$ & $\begin{array}{l}\% \\
2.3^{\circ}\end{array}$ & $2.3^{\%}$ & $4.2^{\%}$ & $\begin{array}{l}\% \\
6.4\end{array}$ \\
\hline $\mathrm{C}_{18}$ & 78.2 & 65.7 & 49.0 & 39.9 & 67.4 & 59.5 \\
\hline $\mathrm{C}_{24}$ & 1.6 & 3.9 & 5.5 & 4.9 & 2.8 & 2.9 \\
\hline$C_{24}^{\Delta 1}$ & 5.7 & 15.9 & 26.4 & 33.1 & 14.1 & 17.0 \\
\hline $\mathrm{C}_{22}-\mathrm{C}_{28}$ & 10.6 & 28.7 & 46.5 & 55.9 & 25.1 & 28.7 \\
\hline
\end{tabular}

フィンゴミェリンに多量に含まれていることは，未知の 重要な生化学的意義起持っているのではないかと推察さ れる。 


\section{森・土肥・三野}

\section{要約}

1. 牛乳と人乳のりえ脂質索珪酸カラムクロマトグラ フィーでケファリン, レシチン，スフィンゴミェリンに 分画，精製した。精製品については赤外線吸収スペクト ルで同定し，薄層クロマトグラフィーでその純度を检定 した.

2. 各々のりえ脂質を $\mathrm{MeOH}-\mathrm{H}_{2} \mathrm{SO}_{4}$ エステル交換法 でメチルエステルとし，ガスクロマトグラフィーで脂肪 酸定定量した。

3. 牛乳ケファリンと人乳ケファリンを比較すると， 人乳は $\mathrm{C}_{18}$ と $\mathrm{C}_{18}^{\Delta 2}$ が多く、, $\mathrm{C}_{18}^{\Delta 1}$ が少ない。また牛乳に は $\mathrm{C}_{22}, \mathrm{C}_{28}, \mathrm{C}_{21}, \mathrm{C}_{24}^{\Delta 1}$ はほとえどないが，人乳には 10\% 以上西つた。

4. レシチンについても人乳は $\mathrm{C}_{18}$ と $\mathrm{C}_{18}^{\Delta 2}$ が多く,

$\mathrm{C}_{16}$ と $\mathrm{C}_{18}^{\Delta 1}$ が少ない。また人乳には $\mathrm{C}_{20} \sim \mathrm{C}_{24}$ が約 $20 \%$ あり、牛乳との差が大きかつた。

5. 著者らの牛乳スフィンゴミエリンの值は $\mathrm{C}_{18}, \mathrm{C}_{18}^{\Delta 1}$, $\mathrm{C}_{18}^{\Delta 2}, \mathrm{C}_{18}^{\Delta 8}$ がすかて少なく, $\mathrm{C}_{22}, \mathrm{C}_{28}, \mathrm{C}_{24}, \mathrm{C}_{24}^{\Delta 1}$ が多く, $70 \%$ 以上あった。牛乳々人乳を比較すると，人乳法 $\mathrm{C}_{18}$,

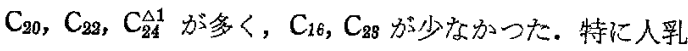
に $\mathrm{C}_{23}$ が少ないのに対し，牛乳に $\mathrm{C}_{28}$ が多いのは大きな 特徵である.人乳，牛乳ともに $\mathrm{C}_{20} \sim \mathrm{C}_{24}$ の制合は $70 \%$ 以上であった。

\section{文献}

1) Badings, H.T. (1962) Neth. Milk and Dairy
J., 16: 217-225.

2）土肥 達・䔟 茂・三野和雄（1967） 日畜会 報，38: $277-285$.

3）古市栄一・近藤 敏・ 川西悟生・西川 勲・中里 溥志・野口洋介・土肥 達・齐藤健輔 (1965) 雪 印乳業技術研究所報告，第６9 号：51-75.

4) Getz, G.S., W. Bertley, F. Stirpe, B.M. Notton and A. Renshaw (1961) Biochem. J., 80: 176-181.

5) Hanahan, D.T., R.M. Watts and D. Pappajohn (1960) J. Lipid Res., 1: 421.

6) HAWKE, J.C. (1963) idid 4: 225-259.

7) Jонм, W.F. (1959) Nutrition Reviews, 17: (8) part II, 29-30.

8) KERR, S.E. and W.W.C. READ. (1963) Biochim. Biophys. Acta., 70: 477-478.

9）工藤 力・両木岱造・長沢太郎（1964）栄養と 食糧, 17: 212-216.

10) Morrison, W.R., E.L. JACK. and L. M. SMith (1965) J. Am. Oil Chem. Soc., 42: 1142-1147.

11) Nelson, G.J. and N.K. Fregman (1960) J. Biol. Chem., 235: 578-583.

12) O'Brien, J. and G. Rouser (1964) J. Lipid Res., 5:339-342.

13) Smith, L.M. and R.R. LowRY (1962) J. Dairy Sci., 45: 581-588.

14) Stgnhagen, S.S. and L. Suennerholm. (1965) J. Lipid Res., 6: 146-155.

15) Sweeley. C.C. (1963) ibid 4: 402-406.

16) 高木 徹 (1964) 化学の領域, 增刊 65 号: 123-142.

17) Tattrie, N.H. and R. Cyr (1963) Biochim. Biophys. Acta., 70: 693-696. 


\title{
Résumé
}

\section{Studies on Conjugated Lipids in Milk}

\section{Fatty Acid Composition of Phospholipids in Cow's Milk and Human Milk}

\author{
Shigeru Mori, Toru Dor and Kazuo MrNo \\ (Research Laboratory, Snow Brand Milk Products Co., Ltd.)
}

1) Cow's milk and human milk phospholipids were separated to cephalin, lecithin and sphingomyelin by silicic acid column chromatography and their purities were checked by infrared spectrometry and thin layer chromatography.

The fatty acids of the phospholipids were esterified by $\mathrm{MeOH}-\mathrm{H}_{2} \mathrm{SO}_{4}$ ester exchange method and analyzed by gas-liquid chromatography.

2) Cow's milk cephalin contains $\mathrm{C}_{16}(12.3 \%), \mathrm{C}_{18}(13.4 \%), \mathrm{C}_{18}^{\Delta 1}(53.5 \%), \mathrm{C}_{18}^{\Delta 2}(5.0 \%)$ and $\mathrm{C}_{20} \sim \mathrm{C}_{24}(6.2 \%)$, and human milk cephalin contains $\mathrm{C}_{16}(8.5 \%), \mathrm{C}_{18}(30.9 \%), \mathrm{C}_{18}^{A 1}(17.5 \%)$, $\mathrm{C}_{18}^{\Delta 8}(14.3 \%)$ and $\mathrm{C}_{24} \sim \mathrm{C}_{24}(20.6 \%)$, as its major constituents.

3) Cow's milk lecithin contains $\mathrm{C}_{18}(30.1 \%), \mathrm{C}_{18}(8.6 \%), \mathrm{C}_{18}^{\Delta 1}(40.5 \%), \mathrm{C}_{1 \mathrm{~B}}^{\Delta 2}(9.0 \%)$ and $\mathrm{C}_{20} \sim \mathrm{C}_{24}(2.5 \%)$ and human milk lecithin contains $\mathrm{C}_{16}(13.7 \%), \mathrm{C}_{18}(25.4 \%), \mathrm{C}_{18}^{\Delta 1}(13.0 \%)$, $\mathrm{C}_{18}^{\Delta 2}(20.8 \%)$ and $\mathrm{C}_{20} \sim \mathrm{C}_{24}(19.3 \%)$. This showed marked differences in $\mathrm{C}_{18}^{\Delta 2}$ and $\mathrm{C}_{20} \sim \mathrm{C}_{24}$ fatty acid composition.

4) Sphingomyelins of both cow's milk and human milk contain large amount (over $70 \%$ ) of long chain saturated fatty acids, especially $\mathrm{C}_{20}, \mathrm{C}_{22}, \mathrm{C}_{23}$ and $\mathrm{C}_{24}$.

Cow's milk sphingomyelin contains $\mathrm{C}_{20}(2.4 \%), \mathrm{C}_{22}(13.1 \%), \mathrm{C}_{28}(25.2 \%), \mathrm{C}_{24}(19.8 \%)$ and $\mathrm{C}_{24}^{\Delta 1}(12.0 \%)$, and human milk sphingomyelin contains $\mathrm{C}_{20}(12.9 \%), \mathrm{C}_{22}(21.8 \%), \mathrm{C}_{23}(5.5 \%)$, $\mathrm{C}_{24}(14.7 \%)$ and $\mathrm{C}_{24}^{\Delta 1}(22.8 \%)$. Cow's milk sphingomyelin is characterized by higher percentage composition of $\mathrm{C}_{28}$, while human milk sphingomyelin is characterized by $\mathrm{C}_{\mathbf{2} \pm}^{\Delta 1}$. 